$12-31-2021$

\title{
Foreword from Handling Editor - 10th Edition
}

\author{
Salfia Rahmawati \\ Department of Anthropology, Faculty of Social and Political Sciences, Universitas Indonesia, Indonesa, \\ salfiarahmawati@ui.ac.id
}

Follow this and additional works at: https://scholarhub.ui.ac.id/ajce

Part of the Social and Behavioral Sciences Commons

\section{Recommended Citation}

Rahmawati, Salfia (2021). Foreword from Handling Editor - 10th Edition. ASEAN Journal of Community Engagement, 5(2).

Available at: https://doi.org/10.7454/ajce.v5i2.1172

Creative Commons License

(c) (i) (2)

This work is licensed under a Creative Commons Attribution-Share Alike 4.0 License.

This Front Matter is brought to you for free and open access by the Universitas Indonesia at ASEAN Journal of Community Engagement. It has been accepted for inclusion in ASEAN Journal of Community Engagement. 


\section{Dear Readers,}

We may have read or heard the following Latin phrase: Dum inter homines sumus, colamus humanitatem, 'as long as we are among humans, let us be humane'. To some extent, even if we are among other creatures, let us be humane. But then, what does it means to be humane? It means having compassion, sympathy, and caring toward others. It means respecting diversity and turning it into collective strength for humanity. It means having an awareness that we need each other as a complicated mutuality. And in this universe, we share not only the same spaces and resources but also the same problems at the same time. Thus, the collaboration of multiparties is needed to solve any kind of community problem. Many issues related to community engagement in exploring, examining, and solving the problems are always multidimensional, taking place anthropological, sociological, economic, political, ecological, and other dimensions.

Along with the understanding, ASEAN Journal of Community Engagement commits to bring up the idea of community engagements in many areas of research from multi-perspectives. It is an honour for us to present this edition with various research on community engagement.

Opening this edition, Kumar brings up the issue of Indian transgender communities. This article examines the movement and development of the transgender community and how the Indian government responds to it. Followed by different sector, Harini et. al. in the second article highlights the issue of community-based rehabilitation. They developed a communitybased rehabilitation program in an elderly nursing home located in district Cipayung, Jakarta. The paper evaluates how the aspect of psychiatric disorders and malnutrition conditions in the nursing home affect CBR program. Thus, it should be assessed and managed comprehensively with the help of nutritionists and psychiatrists to build a well-established CBR program. Another health sector comes up from the article of Ismail et. al., which discusses the importance of international collaboration in raising public awareness to the community towards Covid-19 prevention. Aiming the goals, they involved international student collaboration between UTHM and UIN Sultan Hasanuddin Banten to examine the preventive activities and implement a community service program in Kampung Santri Ciceri Jaya Banten, Indonesia. The study finds the ignorance among people in the site resulting in not fully implementing health protocols. Through the program, they educate and spread the information while giving material support related to health protocols to the residents. Some events like hygiene dormitory competitions and educational talk shows are held as a part to stimulate public involvement, though more creative efforts are still needed as an improvement for further study.

In terms of digital and technology, Sayuno enriches the edition by analysing the social construction of transmedia communities among Filipino children gamers in Minecraft and Roblox. This study aims to explore how child users navigate through various transmedia to socially construct shared meanings of their engagements. In the same region, Clores assessed the research dissemination and utilisation of higher education institutions in Bicol, Philippines. The study finds that research dissemination and utilisation are still constrained by problems of institutional leadership, management, access to dissemination tools, research resources, and motivation of researchers. These factors contribute to the low implementation of research in increasing community capacity and empowerment. Followed by the political sector, Chiakaan et. al. examine how political public relations operated against vote-buying in Nigeria. The study identifies several factors that influence vote-buying in Nigeria, including poverty, lack of education, high cost of election participation forms, and many others. The situation needs 
collective effort to solve such structural problems. Thus, the study recommends implementing political public relations approach by the government and other parties against vote-buying.

Last but not least, two articles by Singh, Crispino and Rocha in the health sector round off this issue. Singh attempts to establish the importance of community engagement and the role of communication in achieving health goals in India. The article analyses the ways, strategy, and mode of action regarding community engagement in planning, execution, and monitoring of services at the ground level of the health sector. In the different region, Crispino and Rocha bring up the issue of healthcare professional practice in the Philippines. It evaluates the advantages and disadvantages of the new law in enhancing the capability of Filipino healthcare professionals through the Continuing Professional Development (CPD) programs. The author highlights the significance of community engagement in forming public education, literacy, and participation on the issue of social justice.

In conclusion, we would like to express our gratitude to the Directorate of Administration, Data, and Management of Research Product and Innovation, Universitas Indonesia, for assisting us with proofreading using ENAGO. We would also like to thank all our authors and especially our dedicated reviewers for their contribution to this edition. Our team will continue to serve you with qualified articles in community engagement. Thus AJCE can further be the most authoritative journal in the field. We hope you find the issue interesting. Enjoy reading!

Warm Regards,

Salfia Rahmawati, S.Hum., M.A.

Managing Editor - ASEAN Journal of Community Engagement 